\title{
"Assessment of the level of business readiness for digitalization using marketing and neural network technologies"
}

\begin{tabular}{|c|c|}
\hline \multirow{5}{*}{ AUTHORS } & Nadiia Yasynska (D https://orcid.org/0000-0002-4039-9453 \\
\hline & Inna Fomichenko id https://orcid.org/0000-0002-9180-9344 \\
\hline & Olena Voloshyna id https://orcid.org/0000-0003-3250-7183 \\
\hline & Lada Byvsheva (D https://orcid.org/0000-0003-2381-8836 \\
\hline & Ekaterina Krikunenko (D https://orcid.org/0000-0003-1530-216X \\
\hline ARTICLE INFO & $\begin{array}{l}\text { Nadiia Yasynska, Inna Fomichenko, Olena Voloshyna, Lada Byvsheva and } \\
\text { Ekaterina Krikunenko (2019). Assessment of the level of business readiness for } \\
\text { digitalization using marketing and neural network technologies. Innovative } \\
\text { Marketing, 15(3), 42-59. doi:10.21511/im.15(3).2019.04 }\end{array}$ \\
\hline DOI & http://dx.doi.org/10.21511/im.15(3).2019.04 \\
\hline RELEASED ON & Friday, 23 August 2019 \\
\hline RECEIVED ON & Wednesday, 22 May 2019 \\
\hline \multirow[t]{2}{*}{ ACCEPTED ON } & Friday, 02 August 2019 \\
\hline & $((c)$ EY \\
\hline LICENSE & $\begin{array}{l}\text { This work is licensed under a Creative Commons Attribution } 4.0 \text { International } \\
\text { License }\end{array}$ \\
\hline JOURNAL & "Innovative Marketing " \\
\hline ISSN PRINT & $1814-2427$ \\
\hline ISSN ONLINE & $1816-6326$ \\
\hline PUBLISHER & LLC "Consulting Publishing Company "Business Perspectives" \\
\hline FOUNDER & LLC "Consulting Publishing Company "Business Perspectives" \\
\hline
\end{tabular}

NUMBER OF REFERENCES

29

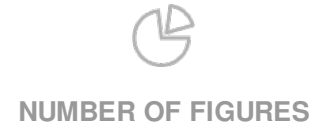

10

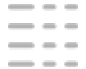

NUMBER OF TABLES

7

(C) The author(s) 2021. This publication is an open access article. 


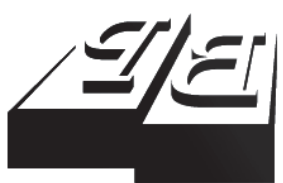

BUSINESS PERSPECTIVES

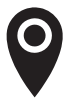

LLC "CPC "Business Perspectives" Hryhorii Skovoroda lane, 10, Sumy, 40022, Ukraine

www.businessperspectives.org

Received on: $22^{\text {nd }}$ of May, 2019 Accepted on: $2^{\text {nd }}$ of August, 2019

(C) Nadiia Yasynska, Inna Fomichenko, Olena Voloshyna, Lada Byvsheva, Ekaterina Krikunenko, 2019

Nadiia Yasynska, Doctor of Economics, Associate Professor, Department of Finance, Accounting and Taxation, Donetsk State University of Management, Ukraine.

Inna Fomichenko, Ph.D. in Economics, Associate Professor, Department of Management, Donbass State Engineering Academy, Ukraine.

Olena Voloshyna, Ph.D., Associate Professor, Department of Management, Donbass State Engineering Academy, Ukraine.

Lada Byvsheva, Ph.D., Associate Professor, Department of Management, Donbass State Engineering Academy, Ukraine.

Ekaterina Krikunenko, Assistant, Department of Intelligent Decision Making Systems, Donbass State Engineering Academy, Ukraine.

\section{(ㄷ)(i)}

This is an Open Access article, distributed under the terms of the Creative Commons Attribution 4.0 International license, which permits unrestricted re-use, distribution, and reproduction in any medium, provided the original work is properly cited.
Nadiia Yasynska (Ukraine), Inna Fomichenko (Ukraine), Olena Voloshyna (Ukraine), Lada Byvsheva (Ukraine), Ekaterina Krikunenko (Ukraine)

\section{ASSESSMENT OF THE LEVEL OF BUSINESS READINESS FOR DIGITALIZATION USING MARKETING AND NEURAL NETWORK TECHNOLOGIES}

\begin{abstract}
The marketing environment of the world economy is changing due to intensive digitalization of trade exchange operations. Formation of marketing forecasts based on current and past periods in modern conditions is irrelevant to the current situation. The purpose of the article is to assess the situational precedents of business readiness for digitalization based on monitoring data, operating environment, applications and management system when using the tools of marketing and neural network modeling. The article uses a systematic approach and methods of statistical, financial and marketing analysis, tools for modeling a neural network. Based on the estimated indicators, the current and forecasted levels of electronic retail in the world are revealed. Based on the application of the concept of portfolio analysis to the data of national and international monitoring, a marketing model of research has been built, in which low business efficiency has been determined, situational modeling of business readiness for digital transformation has been carried out and characteristics of the identified precedents have been given. A low degree of business readiness to digitize the economy has been established. The results emphasize the importance of monitoring business readiness for the digitalization of the economy in real time with marketing and neural network modeling.
\end{abstract}

\section{Keywords}

\section{JEL Classification}

economics, optimization, business, outsourcing, marketplace, cyber-system, electronic retail commerce

\section{INTRODUCTION}

To achieve the evolutionary economic effect of business, decentralized networks of the digital economy, based on knowledge information modeling technologies and improved marketing models, become more efficient. The modern business includes additive technologies in production, marketing and analysis based on new telecommunication standards. The widespread introduction of marketing, industrial and technological innovations requires not only human resources with new competencies, but also organizations capable of introducing and integrating technological innovations into the operational activities of a business. Automation and the use of various algorithms in marketing have always been applied - most of the business tools are based on algorithms.

However, they only simplified complex business tasks and increased work speed. Judging by the recent trends, outsourcing, marketplace and retail are beginning to give way to the services of self-learning bots, whose activities are based on neural network technologies. Business based on neural network technologies is often isolated from 
the rest of the organization of economic activity. Nevertheless, the economic effect of its operation is several times greater than technically and technologically backward economic activity. This, in turn, leads to a modification of the structure of economic and social relations, systems of self-government, organization, processing and modeling of complex socio-economic systems.

Introduction to the business and its organizational components of information technology requires the solution of a large set of tasks. It is fundamentally important that information technologies allow, on the one hand, to obtain generalized analytical information and procure typical protocols for responding to standard situations, on the other hand, to provide an individual approach in each individual case within the framework of cyber physical and social systems. The results obtained and the methods developed will allow the business to more effectively develop corporate marketing strategies for working with clients, which contributes to maintaining and expanding the client network, improving the company's work with each group of clients, increasing the level of customer satisfaction with the level of services provided and, as a result, increasing financial inflows.

Automation of most of the business functions in the context of increasing digitalization of consumer processes increases the variability of possible situations of economic development. This, in turn, can be studied using neural network technologies. This article is devoted to this aspect.

\section{LITERATURE REVIEW}

Analysis of the research suggests that the issues of the development of the digital economy by improving the marketing tools and the system of their circulation, monitoring their effectiveness for business are not well understood. So the challenges of digital transformation are related to the current success of outsourcing, market penetration and retailing. The ways of developing e-commerce and digital transformation of regional economies became the subject of research in the work of Suominen (2017) and Sanchez (2017). Suominen (2017) describes ways to develop e-commerce in Latin America by expanding goods and services, expanding and diversifying exports, optimizing trading and logistics networks, and startups. Recognizing the thoroughness of the e-commerce analysis of the region studied, it is based on pre-dating data and is not valid for reproduction for modeling. Sanchez (2017) highlights the structure and management alternatives in the research models of organization and dynamics of digital transformation, the trends of which are reflected by the World Trade Organization (2018), in Information Economy Report 2017... (2017), data of Raconteur Media Ltd (2017), etc.

The symbiosis of outsourcing, marketplace and retail in its evolutionary basis has generated a complex of financial, consumer goods and services, in which banking and non-banking data are com- bined into a hyper personalized ecosystem that is built on open APIs, programmable money and digital intelligence (Raconteur, 2018).

Modern scientific literature deals with the problem of digitalization of world and economic politics in the Fourth Industrial Revolution's paradigm. According to Petrillo et al. (2018), the results of globalization and competitiveness have made it possible to establish key priorities for the evolution of the Cyber-Physical Systems, to identify the fundamental aspects of the digital transformation of business in line with global trends. The approach to understanding human capital in the intellectual production of Fourth Industrial Revolution is based on the personalization of consumer demand (Petrillo et al., 2018). However, the subject plane of the work is related to the argumentation of the methodological approach to the digitization of economic processes and does not have a methodological justification. The author's approach to solving this problem is presented in the article.

The method proposed by the Working Group on Measurement (Ek \& Spiezia, 2017) for calculating the digital indicator of maturity of the Swedish economy is expanded to include indicators of domestic and international monitoring of the digital transformation and maturity of the Ukrainian economy using neural network modeling tools. 
A significant amount of scientific works is devoted to the optimization of business processes at the enterprises, namely by Gavrylenko and Pavlenko (2008), Lehenchuk, Volska, and Vakun (2016), Gurova and Sadekova (2016), Kovshova (2016), etc. Based on these studies, a generalization of the problem of increasing the effectiveness of digitalization of business processes in Ukraine has been made.

The internet and e-commerce diffusion in several European countries was carried out. By updating the significance of the derivative from the Internet and e-commerce category Networked Readiness Index in this study, this indicator was introduced into the training sample and situational precedents of business readiness for the digitalization of the economy were modeled.

For the most part, business process optimizers are of an organizational and economic nature, generated in the financial indicators of the performance of enterprises and competitiveness in the market. Some scientists grouped methods of business processes optimizing in different ways. So, Kovshova (2016) identifies analytical, instrumental, formal-universal methods, methods of continuous improvement, outsourcing and benchmarking. Gavrylenko and Pavlenko (2008) categorize the methods for business processes optimizing in a slightly different way. These scholars identify formalized universal-principle methods, methods of benchmarking and methods of group work.

The advantage of the research by Rizk (2004) is the use of two groups of approaches to the analysis: micro- and macro-level quantitative and qualitative evaluation. This experience is used in this paper, but its novelty is determined by the study of the level of business readiness for digital transformations based on world trends and observations. However, the work of Rizk (2004) has a geography of only individual countries of the world. In particular, the research is based only on the monitoring of a number of international indices.

The Concept of the development of digital economy and society of Ukraine for 2018-2020 can be considered a significant breakthrough in the state regulation of electronic infrastructure and digitalization of business processes Verkhovna Rada of Ukraine (2018). However, a methodology that would allow monitoring the effectiveness of digitalization of business processes is still missing. In this research, this issue was solved and an assessment of the business performance was proposed based on a set of domestic and international indicators of the digitization of the Ukrainian economy. The objects of scientific research on government regulation are both the business processes themselves and the methods for their optimization, as well as the process approaches to their accounting. However, the methodological foundations and practical prerequisites for the development of economic optimizers of business processes determine the feasibility of further research in this area.

By setting the flaw in the methodology and practice of implementing the digital transformation of the economy, the authors have drawn attention to the choice of the most optimal method for evaluating these changes. To determine the most optimal method of research, the experience of assessing the level of digital transformation has been used for the stated problem (ZekanovićKorona et al., 2014), practice of neural network time series prediction based on multilayer perceptron (Rudenko, Bezsonov, \& Romanyk, 2019; Kruglov \& Borisov, 2002). The article will note the sociological selected research methods for Croatia, Italy, France, Germany and the United Kingdom, which has low effectiveness for practical use in finances. Therefore, in the work on the subject plane of the study, instruments of neural networks were used.

It is believed that the assessment of situational precedents of business readiness for digitalization should be carried out on the basis of monitoring data, operating environment, applications and management system. To this end, a marketing research model should be built.

\section{METHODS}

The study used a systematic approach and methods of statistical, financial and marketing analysis, modeling tools of the neural network. In particular, the study is based on the analysis of descriptive data in marketing, their systematization, 
interpretation and mathematical modeling, the calculation of the integral coefficients of international monitoring and the methodology for calculating the profitability index of economic activity. During the study, the technology of neural network modeling using software was employed, the module Statistica Automated Neural Network (SANN).

The purpose of the paper is to assess the situational precedents of business readiness for digitalization based on monitoring data, operating environment, applications and management system when using the tools of marketing and neural network modeling. The goal was achieved by solving the following tasks:

- a marketing research model has been built, given a generalized understanding of the architecture of cyber-physical and cyber social systems (CFSS) in the digital economy;

- mathematical modeling of situational precedents and the results obtained in the framework of marketing and neural network modeling has been carried out and described.

\section{RESULTS}

\subsection{Problems and trends of business digitalization}

It is believed that the most representative results of business digitalization are marketplace, outsourcing and retail. Being ten years ago as an initial form of intermediary services, outsourcing is spreading, increasing the share of revenue in the formation of a common indicator of the gross national product. In the current stage of world eco- nomic development, formalized universal-principled methods of outsourcing and marketplace are most prevalent. Nowadays, $20 \%$ of enterprises use outsourcing services in the USA and about $10 \%$ in the UK. The market demand for this type of service is increasing due to the digital development of the economy and finance. The development of outsourcing services in the current activities and prospects is represented by countries (see Table 1).

The prerequisites for marketplace potential are: the optimization of customer service (29\%), marketing activities and individual work with customers $(20 \%)$, cross-marketing $(11 \%)$, attractive digital content (10\%), achievements and understanding of customer demands (8\%), use of automation in marketing and logistics in order to increase trade efficiency (6\%), social marketing (5\%), Internet opportunities and devices to boost sales (4\%), services at the location of the sale place $(4 \%)$, public events to improve the brand rating $(2 \%)$, and other (1\%). So, the forecast of global e-retail by country is given in Table 2.

The use of the technical capabilities of the cloud industry of the global network and the increase in non-cash transactions based on block chain technologies require businesses, on the one hand, to make significant capital investment, and on the other hand, serious business ideas. The 10 largest online-sales countries have the following number of URLs (units): Japan (14), Germany (17), United Kingdom (32), China (7), India (1), Canada (33), France (12), Italy (8), Spain (8), Mexico (9) (E-Retailer Global Expansion Report, 2018). The top 10 largest retail companies in the world have the following business indicators (Table 3).

Table 1. The rating of European countries in the strategic vision of the development of outsourcing business (worldwide and European ratings)

Source: Built by the authors based on Coleman (2015), Index of Raconteur Media Ltd (2017).

\begin{tabular}{|c|c|c|c|c|c|}
\hline Country & Worldwide & European & Country & Worldwide & European \\
\hline Bulgaria & 9 & 1 & Estonia & 22 & 6 \\
\hline Poland & 11 & 2 & Latvia & 23 & 7 \\
\hline Lithuania & 15 & 3 & UK & 27 & 8 \\
\hline Germany & 17 & 4 & Hungary & 31 & 9 \\
\hline Romania & 18 & 5 & Spain & 32 & 10 \\
\hline
\end{tabular}


Source: Built and calculated by the authors based on Index of Raconteur Media Ltd (2017).

\begin{tabular}{|c|c|c|c|c|c|c|c|c|c|c|c|c|}
\hline \multirow{2}{*}{ Country } & 2015 & 2016 & 2017 & 2018 & 2019 & 2020 & 2016 & 2017 & 2018 & 2019 & 2020 & \multirow{3}{*}{ Trend } \\
\hline & \multicolumn{6}{|c|}{ Years } & Actual & \multicolumn{4}{|c|}{ Planned } & \\
\hline \multicolumn{7}{|c|}{ Worldwide electronic retail commerce, sales in USD bln } & \multicolumn{5}{|c|}{ Chain substitution method, \% } & \\
\hline China & 663.05 & 899.09 & $1,192.19$ & $1,547.47$ & $1,946.71$ & $2,415.87$ & 135.60 & 132.60 & 129.80 & 125.80 & 124.10 & \multirow{12}{*}{$\downarrow$} \\
\hline USA & 342.96 & 396.72 & 457.02 & 524.66 & 600.21 & 684.24 & 115.68 & 115.20 & 114.80 & 114.40 & 114.00 & \\
\hline UK & 92.25 & 103.78 & 114.15 & 124.43 & 134.69 & 145.33 & 112.50 & 109.99 & 109.01 & 108.25 & 107.90 & \\
\hline Japan & 73.3 & 77.41 & 81.28 & 84.93 & 88.33 & 91.51 & 105.61 & 105.00 & 104.49 & 104.00 & 103.60 & \\
\hline Germany & 51.7 & 57.65 & 63.93 & 69.05 & 73.19 & 77.22 & 111.51 & 110.89 & 108.01 & 106.00 & 105.51 & \\
\hline South Korea & 36.15 & 39.77 & 43.35 & 47.03 & 50.37 & 52.89 & 110.01 & 109.00 & 108.49 & 107.10 & 105.00 & \\
\hline France & 35.62 & 38.55 & 51.54 & 44.51 & 47.4 & 50.24 & 108.23 & 133.70 & 86.36 & 106.49 & 105.99 & \\
\hline Canada & 23.18 & 26.62 & 30.3 & 34.38 & 38.85 & 43.63 & 114.84 & 113.82 & 113.47 & 113.00 & 112.30 & \\
\hline India & 13.31 & 23.39 & 37.5 & 52.54 & 65.09 & 79.41 & 175.73 & 160.32 & 140.11 & 123.89 & 122.00 & \\
\hline Australia & 16.43 & 18.34 & 20.36 & 22.46 & 24.7 & 27.05 & 111.63 & 111.01 & 110.31 & 109.97 & 109.51 & \\
\hline Other countries & 200.38 & 233.35 & 260.76 & 308.15 & 348.66 & 390.51 & 116.45 & 111.75 & 118.17 & 113.15 & 112.00 & \\
\hline Total & $1,548.33$ & $1,914.67$ & $2,352.38$ & $2,859.61$ & $3,418.2$ & $4,057.9$ & 123.66 & 122.86 & 121.56 & 119.53 & 118.71 & \\
\hline $\begin{array}{l}\text { The size of world e-commerce sales in the } \\
\text { global sales, trillion US dollars (\%) }\end{array}$ & $1.5(7.4)$ & $1.92(8.7)$ & $2.35(10)$ & $2.86(11.5)$ & $3.42(13)$ & $4.1(14.6)$ & \multirow{2}{*}{\multicolumn{5}{|c|}{ - }} & $\uparrow$ \\
\hline $\begin{array}{l}\text { The size of world electronic purchases in the } \\
\text { global sales, trillion US dollars (\%) }\end{array}$ & $1.48(11.7)$ & $1.62(9.9)$ & $1.77(9.2)$ & $1.91(8.1)$ & $2.05(7.4)$ & $2.19(6.8)$ & & & & & & $\downarrow$ \\
\hline
\end{tabular}


Table 3. TOP-10 retail companies of the world in 2016

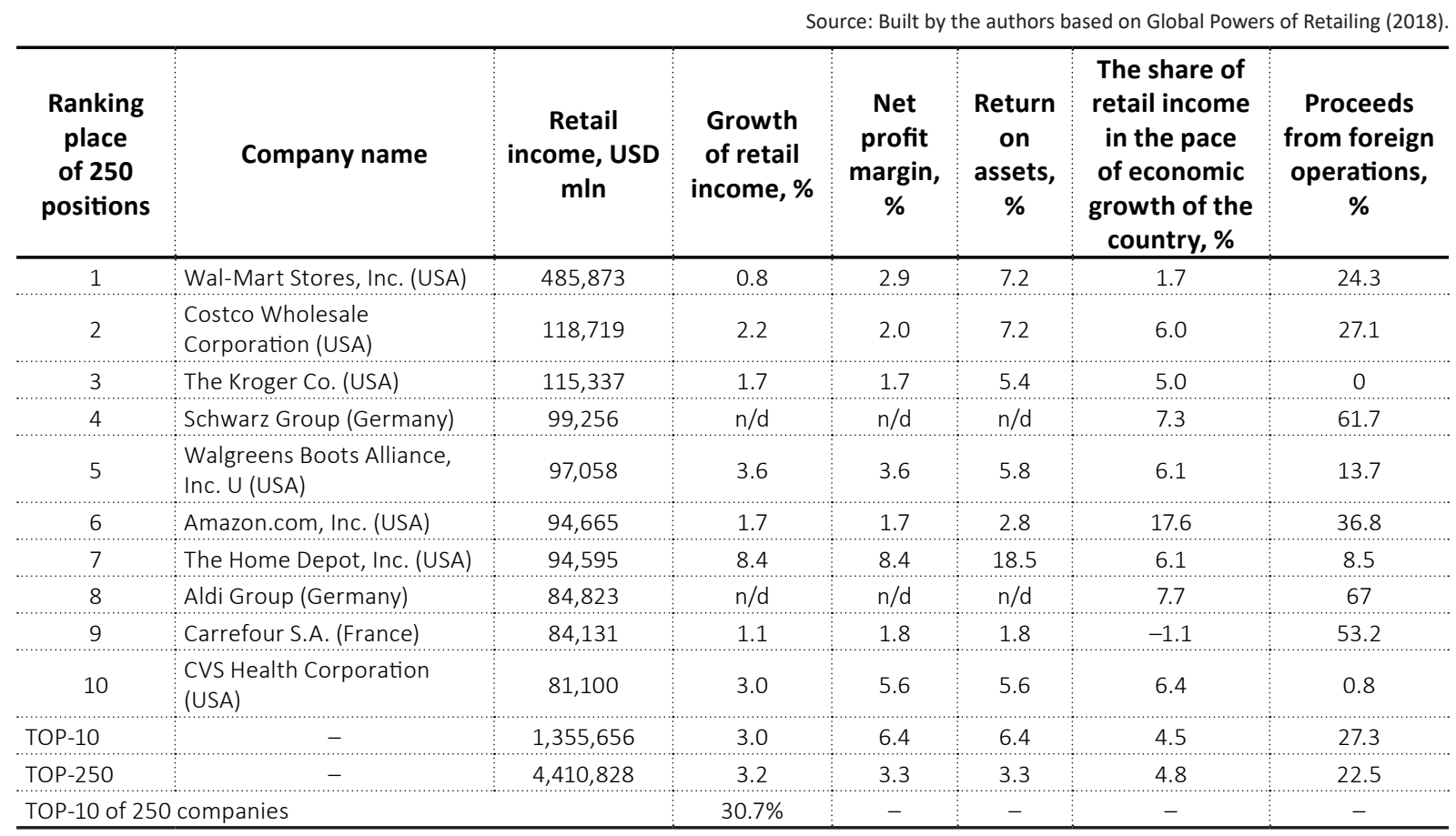

There are more than 21 online sales aggregators in Ukraine now. Among them are Ava, E-Katalog, Freemarket, Hotline, Hotprice, I-M, etc. Products that provide social networking, programs that quickly process large amounts of data, their own mobility, cloud services, cyber security, and Internet market are the most marketable in the retail market.

The expected benefits from digitalization of the global economy are recognized (in the ranking from 1 to 5) (Everett, 2015) by operational efficiency (4.9), staff reduction (3.8), transformation time (3.7), gaining competitive advantage (3.4), standardization (3.2), improved analytics (2.1). The forecast of regional e-commerce in the world is given in Table 4.
The statistical and reporting data of these documents have been used to summarize the world and regional trends in the digitization of the economy and the development of e-commerce.

\subsection{Building a marketing research model}

To substantiate the key positions of the strategy for the development of the digital economy of any country, according to the current state priorities, the article uses the BCG (Boston Consulting Group) matrix methodology. Based on the chosen subject plane of research and actualization of this problem, it is believed that the most effective indicators of the economy digitization are profitability indices of the country's economic activity, the ICT

Table 4. World e-commerce by regions (forecast), sales, \%

Source: Built by the authors based on the Index of Raconteur Media Ltd (2017).

\begin{tabular}{|c|c|c|c|c|c|c|c|}
\hline \multirow{2}{*}{ Region } & \multicolumn{7}{|c|}{ Years } \\
\hline & 2015 & 2016 & 2017 & 2018 & 2019 & 2020 & 2020-2015 \\
\hline Asia Pacific & 53 & 56 & 60 & 63 & 65 & 67 & 126.42 \\
\hline North America & 25 & 23 & 22 & 19 & 18 & 17 & 68.00 \\
\hline Western Europe & 14 & 13 & 10 & 10 & 9 & 8 & 57.14 \\
\hline Central and Eastern Europe & 3 & 3 & 3 & 3 & 3 & 3 & 100.00 \\
\hline Latin America & 3 & 3 & 3 & 3 & 3 & 3 & 100.00 \\
\hline Middle East and Africa & 2 & 2 & 2 & 2 & 2 & 2 & 100.00 \\
\hline
\end{tabular}




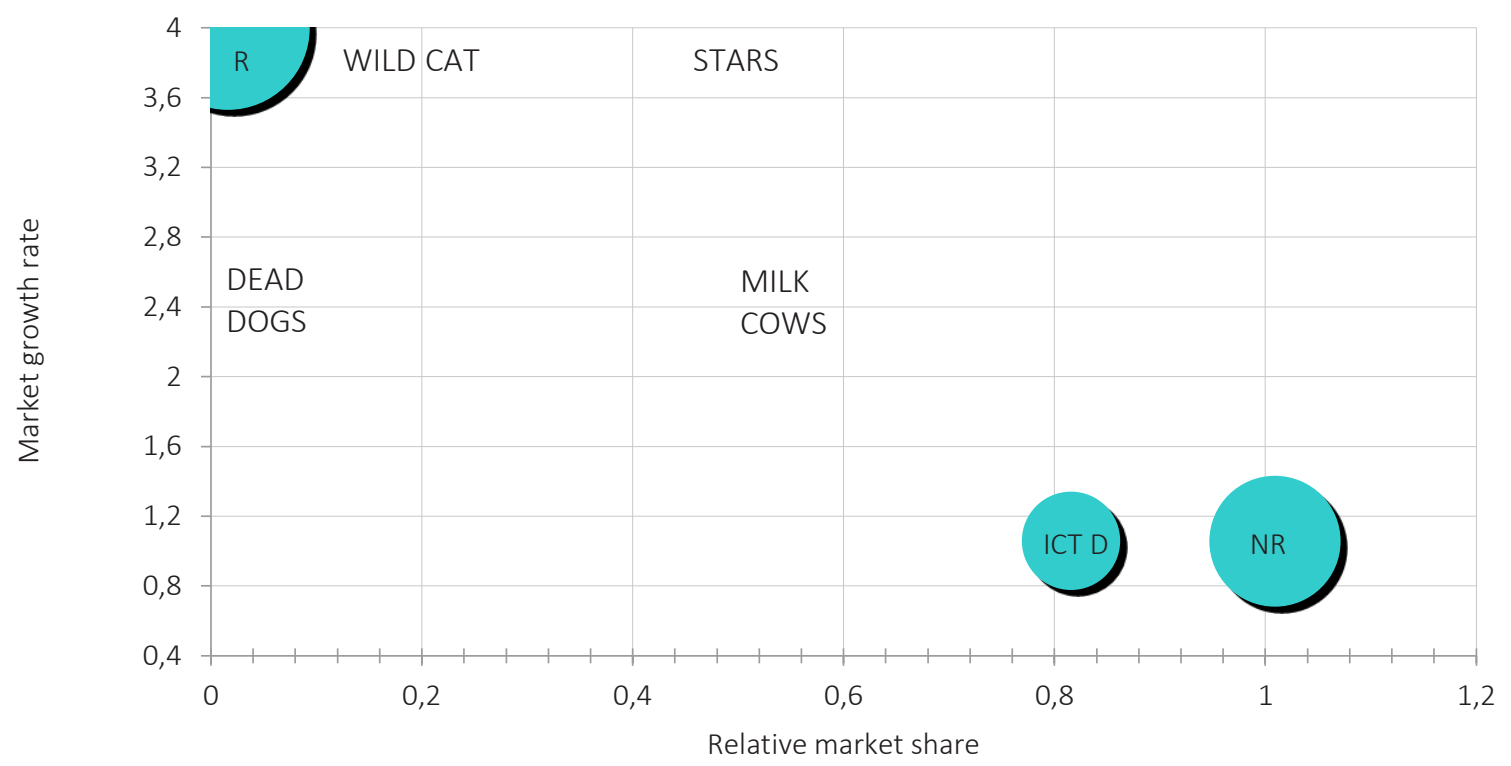

Figure 1. Results of marketing analysis of digital process perspectives for the modified BCG matrix

(Information and Communications Technology) Development Index and Networked Readiness Index. The results are presented in Figure 1.

To determine the relative market share, statistical information was used from Poland, the closest strategic partner of Ukraine. Having built the BCG matrix, it has been revealed that the factors that, according to the authors, in the current situation affect the digitalization of business, are profitability indices of the country's economic activity (in Figure $1-\mathrm{R}$ ), the ICT Development Index (in Figure 1 - ICT D) and Networked Readiness Index (in Figure 1 - NR). According to the concept of the BCG matrix and the results of the analysis it was revealed that the factors determining ICT Development Index and Networked Readiness Index, according to the behavior strategy, are characterized by a large market share, with a low growth rate. They do not require costly investment while bringing a stable and high income. This income for the digital economy is used to finance other areas and types of businesses. Regarding the gross profitability of the economy, the relative share in the formation of the market is small, but sales growth rates are high. To increase their market share, substantial investment is required optimally in innovative products. At the same time, the economy's ability to consume acquires the greatest importance. Accordingly, these indicators can be independent factors for the resultant - total consumer costs.
Based on the fact that marketing analysis of a market means assessing, defining, modeling and forecasting processes and market phenomena using economic, statistical and other research methods, a marketing model will be built and certain assumptions will be formed as well:

- outsourcing, marketplacing and retail are the basis of modern digital business transformation in its functional and target categories;

- the observation period is limited by the time from the moment of intensification of electronic sales to the next year, for which statistical data are available;

- market capacity - sales statistics for the economy as a whole are taken into account;

- digitalization level - statistical data on international monitoring of networked business readiness and level of ICT development were taken into account;

- the number of suppliers in the market is not an impact factor, since under digitization of exchange operations, tighter competition, openness of the economy and diminishing resources (access to them) this factor is leveled;

- in the conditions of digital transformation, goods began to be called logistics services for 
finding, purchasing, delivering and paying for what was previously called goods;

- based on the network marketing campaign in internet content, the uniqueness of the dominant participant position in the network determines the response of end users;

- the basis of the exchange operations were cyber-systems, which in real time are sort exogenous, intermediate and target parameters of the marketing model. While functioning on the basis of cyber-systems, marketing models are functional.

Impact of the business processes digitization is concerned to the speed of conversion of working time to value-added product (or net financial result). Usually during the study of the effectiveness or efficiency of the business entities, functioning attention is paid to the optimization of business processes of production, logistics or technological content.

\subsection{Generalization of the notion of CPSS architecture in the digital economy}

Modern business process optimizers are in line with the hierarchical basis of the digital economy. Hierarchical basis of the digital economy, according to the authors creates a symbiosis of CFSS, in which software is a social object. The CFSS information and resource inquiries not only work on receiving information and other resources, but also on the analytical processing and execution of the request. It is believed that the CPSS in the digital economy has the following components (Figure 2).

The internal block of information processing, namely recources, contains model decoders (OMG, 2019), a tree of goals, a tree of architectural management decisions of the maximum possible alternatives. Accordingly, an appropriate interface of software and hardware architecture should have an impressive set of behavioral protocols for

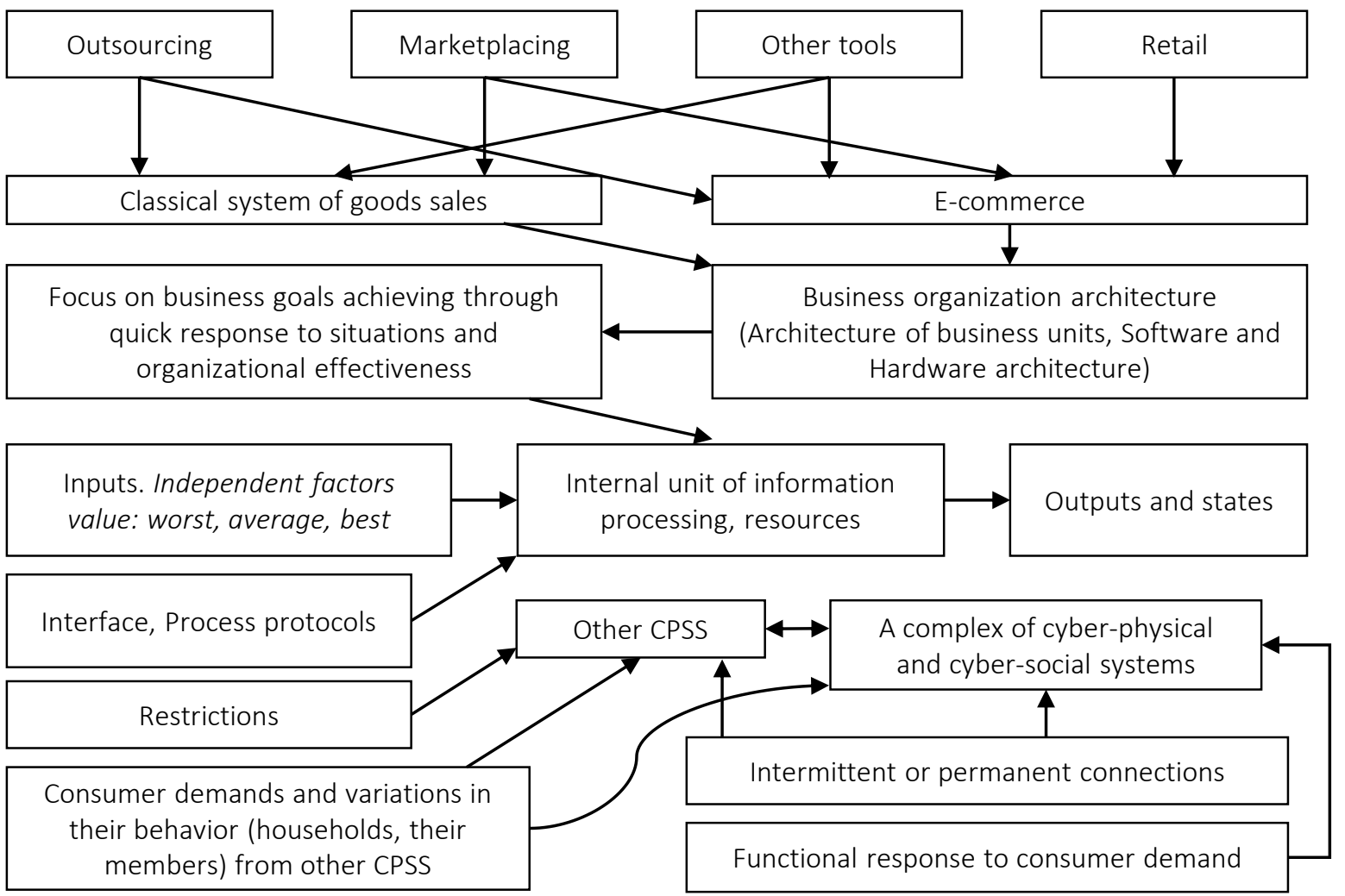

Note: The terminology "architecture", "system", "architecture of business units", "software architecture", "business organization architecture" is borrowed from Eeles (2006), A Conceptual Model of Architecture Description (2000).

Figure 2. Generalized view of the CPSS architecture in the digital economy 
optimal automatic production, logistics, financial and other business activities. Note also that the behavioral protocols should focus on the ultimate function of the business in the form of customer satisfaction at each particular point in time.

The main element of the CPSS is the collection and evaluation of information from a dynamic and undefined physical environment, which must be transformed into useful knowledge in real time. So, $C P S S$ is defined as the following entry:

$$
\operatorname{CPSS}(y)=\left\langle\operatorname{Rel}, W I, \operatorname{Reg}\left(x_{1}, \ldots, x_{n}\right)\right. \text {, }
$$

Resp, $S$, Const, $I, P, O\rangle$.

In general, a CPSS is a combinable and programmable object containing an internal unit for processing information, resources $P$ and an interface $W I$, that waits for consumer requests $\operatorname{Reg}\left(x_{1}, \ldots, x_{n}\right)$ from other $\operatorname{CPSS}\left(j_{1}, \ldots, j_{n}\right)$ and corresponds to them Resp. The CPSS processing unit receives inputs $I$, produces outputs $O$, and has states $S$. Its compounds define intermittent or permanent connections of $\mathrm{Rel}$ with other CPSS. These relationships are connections established under specific sets of constraints Const. Based on this, for the CPSS of household consumption, an integral indicator can be calculated from three others: the profitability of the country's economic activity, the level of development of ICT Development Index and Network Readiness.
Typical features of the presented CPSS architecture are digital transformation of production and sales processes using artificial systems for modeling variational scenarios between computational and physical resources in real time and infrastructure operation control protocols.

At the moment, CPSS combines cyber launch, computer hardware and software technologies, qualitatively new actuators that are built into the environment in the mode of perception of changes, response to them, self-study and adaptation.

\subsection{Mathematical modeling of situational precedents and description of the results obtained in the framework of marketing and neural network modeling}

Formation of a net financial result of enterprises directly depends on the used means of exchange of basic and financial resources, as well as requests of end consumers (household members) to meet their complex needs. According to the Concept of Development of the Digital Economy and Society of Ukraine for 2018-2020 (Verkhovna Rada of Ukraine (2018), the main purpose of digitization is to achieve digital transformation of existing and creation of new industries, as well as the transformation of living environment into new, more efficient and modern, and one of the steps is determin-

Table 5. The dynamics of independent factors and the resulting indicator

Source: Calculated by the authors based on The Networked Readiness Index. Reports (2010-2016), Measuring the Information Society Reports (2014-2017), Ukrainian statistical data (2010-2017), State Statistics Service of Ukraine (2019).

\begin{tabular}{|c|c|c|c|c|c|c|c|c|c|c|c|}
\hline \multirow{2}{*}{\multicolumn{2}{|c|}{ Index, Ukraine }} & \multicolumn{2}{|c|}{ Indicator } & 2010 & 2011 & 2012 & 2013 & 2014 & 2015 & 2016 & 2017 \\
\hline & & \multicolumn{8}{|c|}{ Years } & & \\
\hline \multicolumn{2}{|c|}{$\begin{array}{l}\text { Networked } \\
\text { Readiness Index } \\
\text { ( } 7=\text { Best) }\end{array}$} & \multirow{3}{*}{$\begin{array}{c}x \\
\text { (independent } \\
\text { factors) }\end{array}$} & $x_{1}$ & 3.53 & 3.53 & 3.85 & 3.87 & 3.87 & 4.0 & 4.2 & $4.44^{*}$ \\
\hline \multicolumn{2}{|c|}{$\begin{array}{l}\text { ICT Development } \\
\text { Index }(10=\max )\end{array}$} & & $x_{2}$ & 4.41 & 4.64 & 4.97 & 5.15 & 5.19 & 5.23 & 5.31 & 5.62 \\
\hline \multicolumn{2}{|l|}{$\operatorname{Rent}_{\mathrm{val}} * *$} & & $x_{3}$ & 0.02 & 0.04 & 0.02 & 0.0003 & -0.16 & -0.08 & 0.01 & 0.04 \\
\hline \multirow[b]{2}{*}{$\begin{array}{l}\text { Total } \\
\text { consumer } \\
\text { costs }\end{array}$} & UAH & \multirow{2}{*}{\multicolumn{2}{|c|}{$y$ (resulting indicator) }} & $2,762.89$ & $3,115.66$ & $3,261.63$ & $3,445.91$ & $3,708.79$ & $4,600.41$ & $5,331.41$ & $6,632.50$ \\
\hline & $\begin{array}{l}\% \text { of } \\
\text { indicator } \\
z^{* * *}\end{array}$ & & & 89.9 & 90.1 & 90.8 & 90.2 & 91.6 & 92.9 & 93.2 & 92.9 \\
\hline
\end{tabular}

Notes: * Current indicator is modeled based on the calculation of the trend line with the highest coefficient of determination obtaining value due to the lack of statistical data. ${ }^{* *}$ The following formula is used Rent $=$ (Profit Business) / (Business Revenues). *** Total average monthly expenses per one household, UAH. 
ing indices, indicators and methods for assessing the digital development of Ukraine in accordance with international practices. On the basis of the components identified while building a marketing model, a neural network model will be developed and constructed for business readiness for digital transformations in the economy in the dynamics of changes in the components of the marketing model. Therefore, to model a possible digital consumer boom, the dynamics of profitability indices of the country's economic activity $\left(\operatorname{Rent}_{V a l} ; x_{3}\right)$, the ICT Development Index $\left(x_{2}\right)$ and Networked Readiness Index $\left(x_{1}\right)$ are used (Table 5).

This publication has the opportunity to give a detailed presentation of the results of combining the foundations of marketing and neural network modeling in the subject plane of the study of business readiness for digital transformations of housekeeping and sales. Since the task to be solved should be attributed to the regression analysis tasks, it is, therefore, advisable to use the following types of neural networks, namely, multilayer perceptron and radial basis networks (Rudenko et al., 2019).

According to the statement of the KolmogorovArnold-Hecht-Nielsen theorem for determining the required number of synaptic weights, $L w$ in a multilayer network (Kruglov, 2002) should be determined:

$$
\begin{aligned}
& \frac{m^{\prime} \cdot N^{\prime}}{1+\log _{2} N^{\prime}} \leq L w \leq m^{\prime} \cdot\left(\frac{N^{\prime}}{m^{\prime}}+1\right) \times \\
& \times\left(n^{\prime}+m^{\prime}+1\right)+m^{\prime},
\end{aligned}
$$

where $n^{\prime}$ - input signal dimension, $m^{\prime}$ - output signal dimension, $N^{\prime}$ - number of elements of the training set.
The number of neurons in the hidden layers $L^{\prime \prime}$ (Kruglov, 2002):

$$
L^{\prime \prime}=\frac{L w}{n^{\prime}+m^{\prime}},
$$

where $L^{\prime \prime}$ - number of neurons in hidden layers of the neural network.

The initial data to construct mathematical model based on neural networks are presented in Table 6 . Based on these data, the required number of synaptic weights of $L w$ will be determined.

$$
\begin{gathered}
\frac{1 \cdot 5}{1+\log _{2} 5} \leq L w \leq 1 \cdot\left(\frac{5}{1}+1\right) \cdot(3+1+1)+1, \\
1,505 \leq L w \leq 43, \\
0,251 \leq L^{\prime \prime} \leq 7,167 .
\end{gathered}
$$

Statistical 13 Trial software package for data was used to conduct statistical analysis in order to build a mathematical model of a neural network. The base of initial data is automatically divided into training, control and test samples in the module SANN. The following mathematical models of the neural networks of influence of the business processes digitization were obtained during the construction (Table 6).

For instance, RBF 3-5-1 is a radial basis function network, which consists of 5 inputs, on a hidden layer -5 neurons and 1 output.

Given that there are several runs of the learning algorithm, neural network is chosen under the number 2 MLP 3-4-1, which has the highest per-

\begin{tabular}{|c|c|c|c|c|c|}
\hline Index & Network name & $\begin{array}{c}\text { Training } \\
\text { performance }\end{array}$ & Test performance & Training error & Test error \\
\hline 1 & RBF* 3-5-1 & 0.910829 & 0.000000 & 0.014722 & 0.000001 \\
\hline 2 & MLP** 3-4-1 & 0.991892 & 0.000000 & 0.001464 & 0.000070 \\
\hline 3 & MLP 3-2-1 & 0.835935 & 0.000000 & 0.026666 & 0.005860 \\
\hline 4 & MLP 3-6-1 & 0.909299 & 0.000000 & 0.015323 & 0.003050 \\
\hline 5 & RBF 3-3-1 & 0.886306 & 0.000000 & 0.018311 & 0.001485 \\
\hline
\end{tabular}
formance in the above sample sets and only four neurons in the hidden layer, that is, a simplified architecture.

Table 6. Results of mathematical models of neural networks of the impact of the business processes digitization, which showed the highest performance in the training, control and test samples

Note: * Radial basis function network, ** multilayer perceptron. 


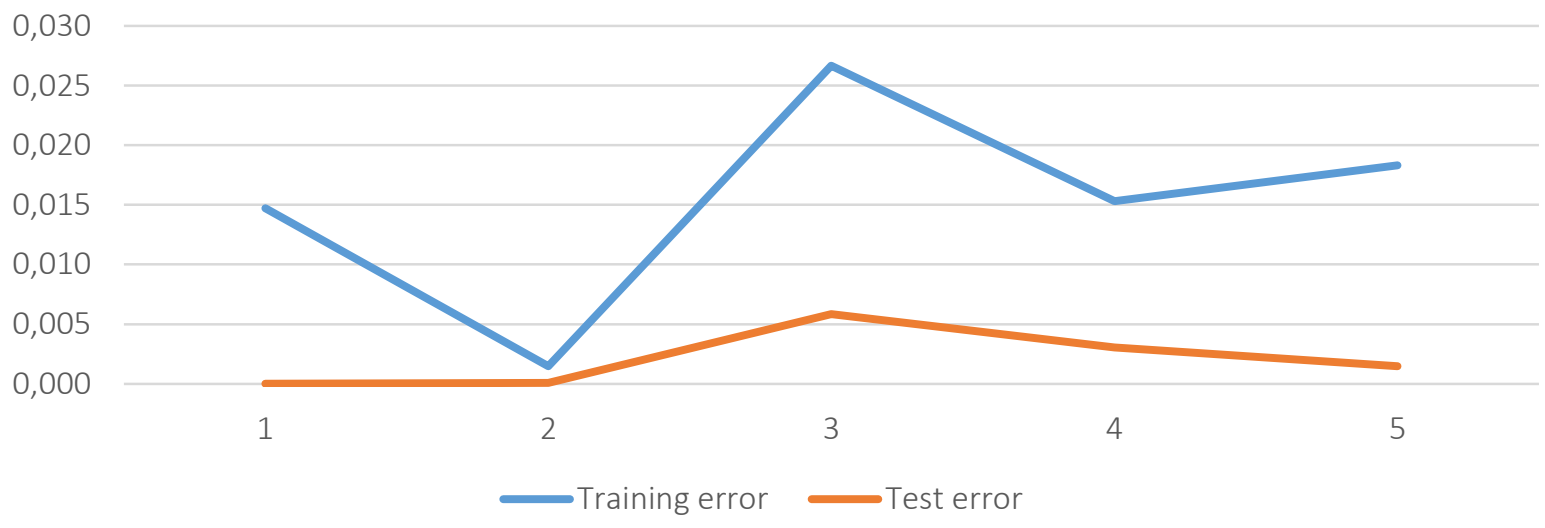

Figure 3. Errors in training educational and test samples of mathematical models of neural networks, the influence of the business processes digitization, which showed the highest performance

Results of mathematical models of neural networks of the influence of the business processes digitization, namely, learning errors of training and test samples, are demonstrated in Figure 3.

The scatter diagram of the calculated and actual values of the resulting indicator of the mathematical model of a neural network and impact of the digitization of business processes such as the MLP 3-4-1 type are presented in Figure 4.

Based on the obtained mathematical model of the neural network of the influence of modern economic optimizers on the digitalization of business processes such as MLP 3-4-1, which proved its adequacy, situational modeling of business readiness will be performed for digital transformations on the following output data presented in Table 7.

While determining the resulting indicator, the following results were obtained (Figures 4-9). In case of permanence of $\mathrm{X}_{2}$ and $\mathrm{X}_{3}$ and the existence of three of $\mathrm{X}_{1}$ mentioned scenarios, the level of household's total expenditures remains at $6.8 \%$ (100\%-93.2\%) to 6,181.49 UAH (Figure 5).

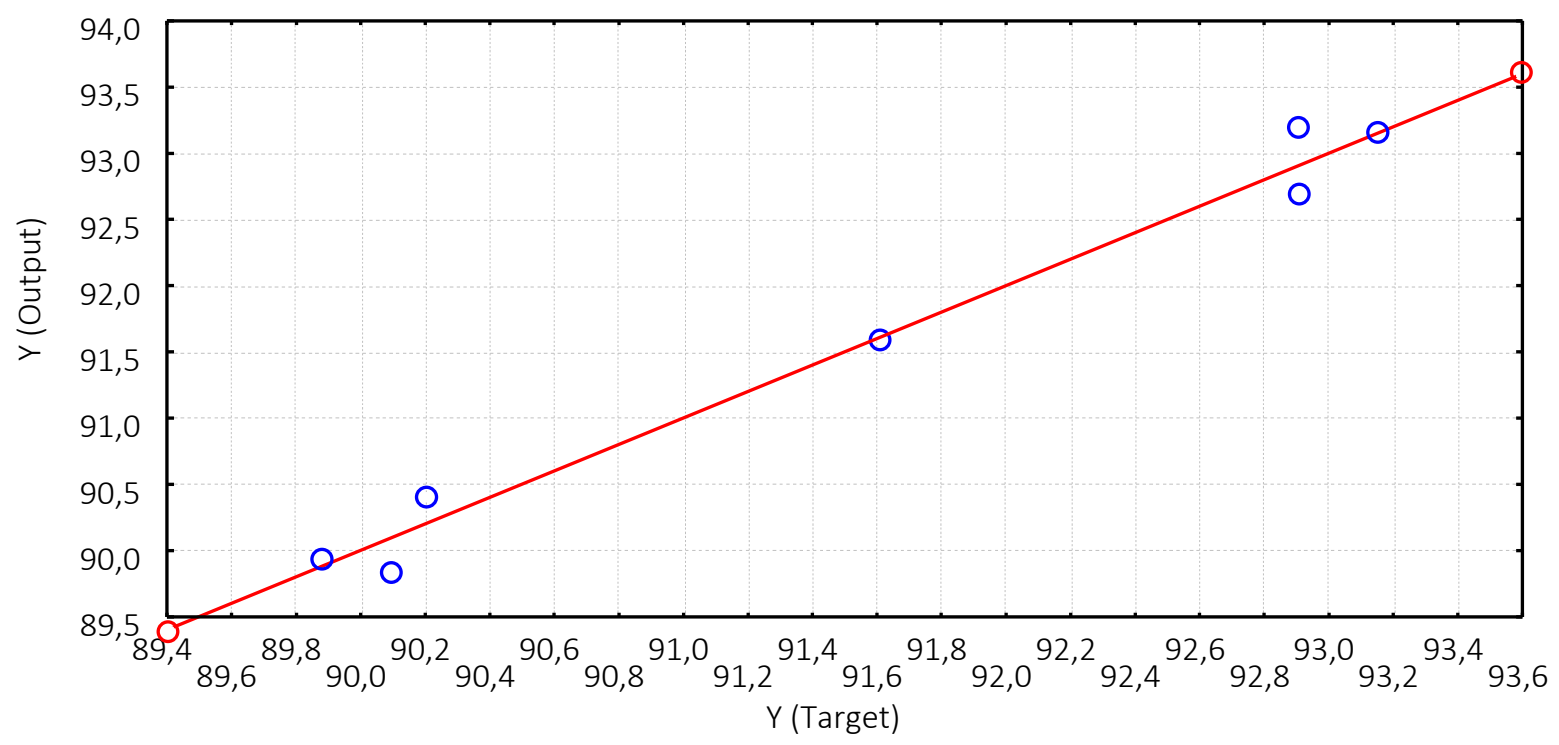

Figure 4. Scatter diagram of calculated and actual value of a resulting indicator of the mathematical model of neural network, influence of the digitization of business processes such as MLP 3-4-1 
Table 7. Baseline data for situational modeling of independent factors influencing the business processes digitization based on the design of artificial neural network at worst, average and best script

\begin{tabular}{|c|c|c|c|c|c|c|c|}
\hline Version & $x_{1}$ & $x_{2}$ & $x_{3}$ & Version & $x_{1}$ & $x_{2}$ & $x_{3}$ \\
\hline $1(2017)$ & 4.440 & 5.620 & 0.040 & 12 & 5.940 & 7.620 & 0.040 \\
\hline 2 & 5.440 & 5.620 & 0.040 & 13 & 6.440 & 8.620 & 0.040 \\
\hline 3 & 5.940 & 5.620 & 0.040 & 14 & 4.440 & 6.620 & 0.300 \\
\hline 4 & 6.440 & 5.620 & 0.040 & 15 & 4.440 & 7.620 & 0.350 \\
\hline 5 & 4.440 & 6.620 & 0.040 & 16 & 4.440 & 8.620 & 0.400 \\
\hline 6 & 4.440 & 7.620 & 0.040 & 17 & 5.440 & 5.620 & 0.300 \\
\hline 7 & 4.440 & 8.620 & 0.040 & 18 & 5.940 & 5.620 & 0.350 \\
\hline 8 & 4.440 & 5.620 & 0.300 & 19 & 6.440 & 5.620 & 0.400 \\
\hline 9 & 4.440 & 5.620 & 0.350 & 20 & 5.440 & 6.620 & 0.300 \\
\hline 10 & 4.440 & 5.620 & 0.400 & 21 & 5.940 & 7.620 & 0.350 \\
\hline 11 & 5.440 & 6.620 & 0.040 & 22 & 6.440 & 8.620 & 0.400 \\
\hline Independent & \multirow{2}{*}{\multicolumn{2}{|c|}{ Optimal value }} & \multicolumn{5}{|c|}{ Version, the independent factor value } \\
\hline factor & & & & & & Average & Best \\
\hline$x_{1}$ & \multicolumn{2}{|c|}{7 (Best) } & \multicolumn{2}{|c|}{5.44} & 5.94 & \multicolumn{2}{|c|}{6.44} \\
\hline$x_{2}$ & \multicolumn{2}{|c|}{$10(\max )$} & \multicolumn{2}{|c|}{6.62} & 7.62 & \multicolumn{2}{|c|}{8.62} \\
\hline$x_{3}$ & \multicolumn{2}{|c|}{ (growth) } & \multicolumn{2}{|c|}{0.3} & 0.35 & \multicolumn{2}{|c|}{0.4} \\
\hline
\end{tabular}

In the case of the static nature of the indicator $\mathrm{X}_{1}$ and other two, there are eight variants of "drawdown" of total consumer spending. For any growth, provided for by three development scenarios, the level of consumer total expenditure of households remains at the level of $93.2 \%$. This gives grounds to assert that this independent factor remains one of the priorities for the further revitalization of electronic sales, and is not monopoly defining.

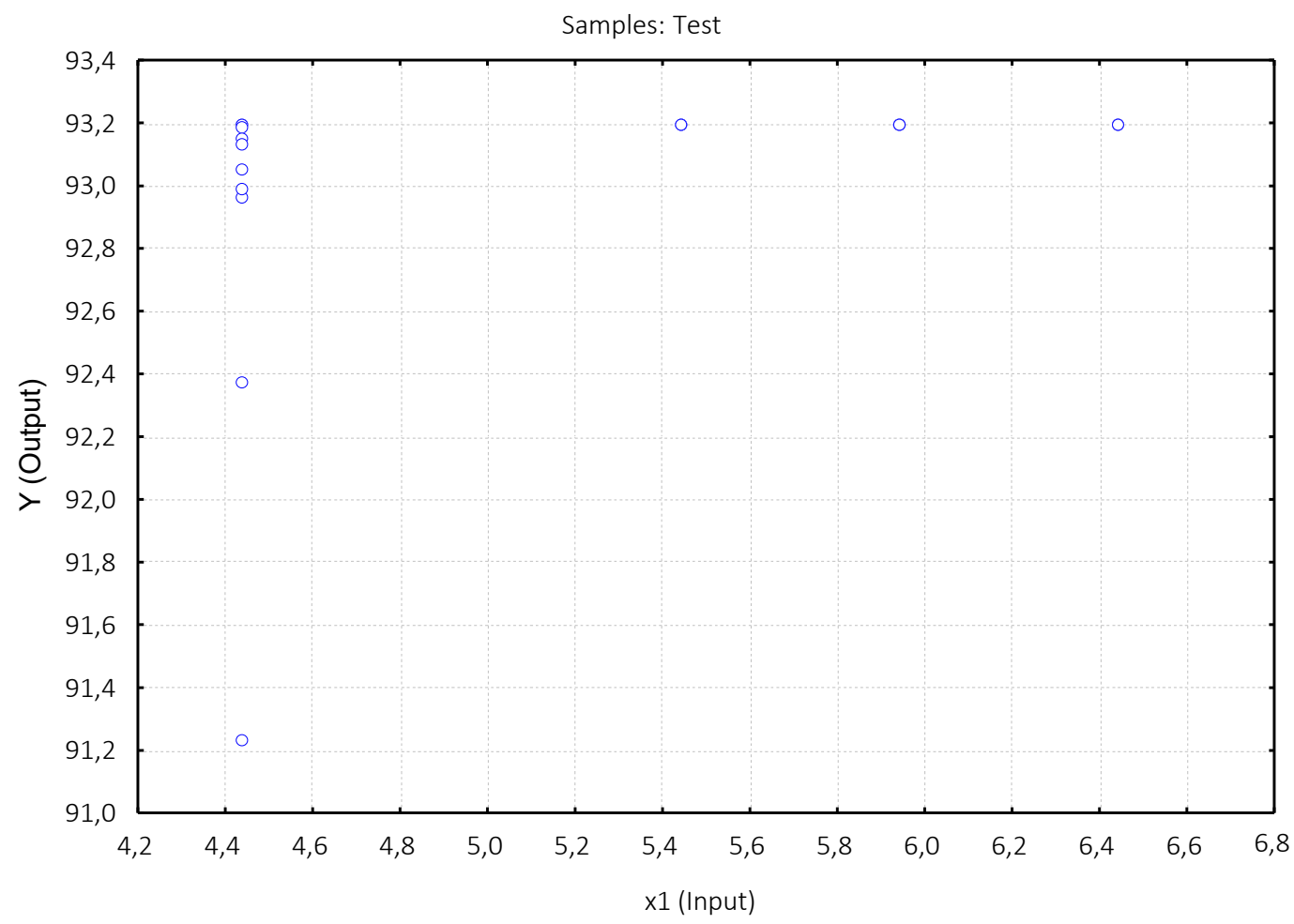

Figure 5. Mathematical dependence of the resulting indicator $(y)$ and independent variable $x_{1}$ on the type MLP 3-4-1 neural network 


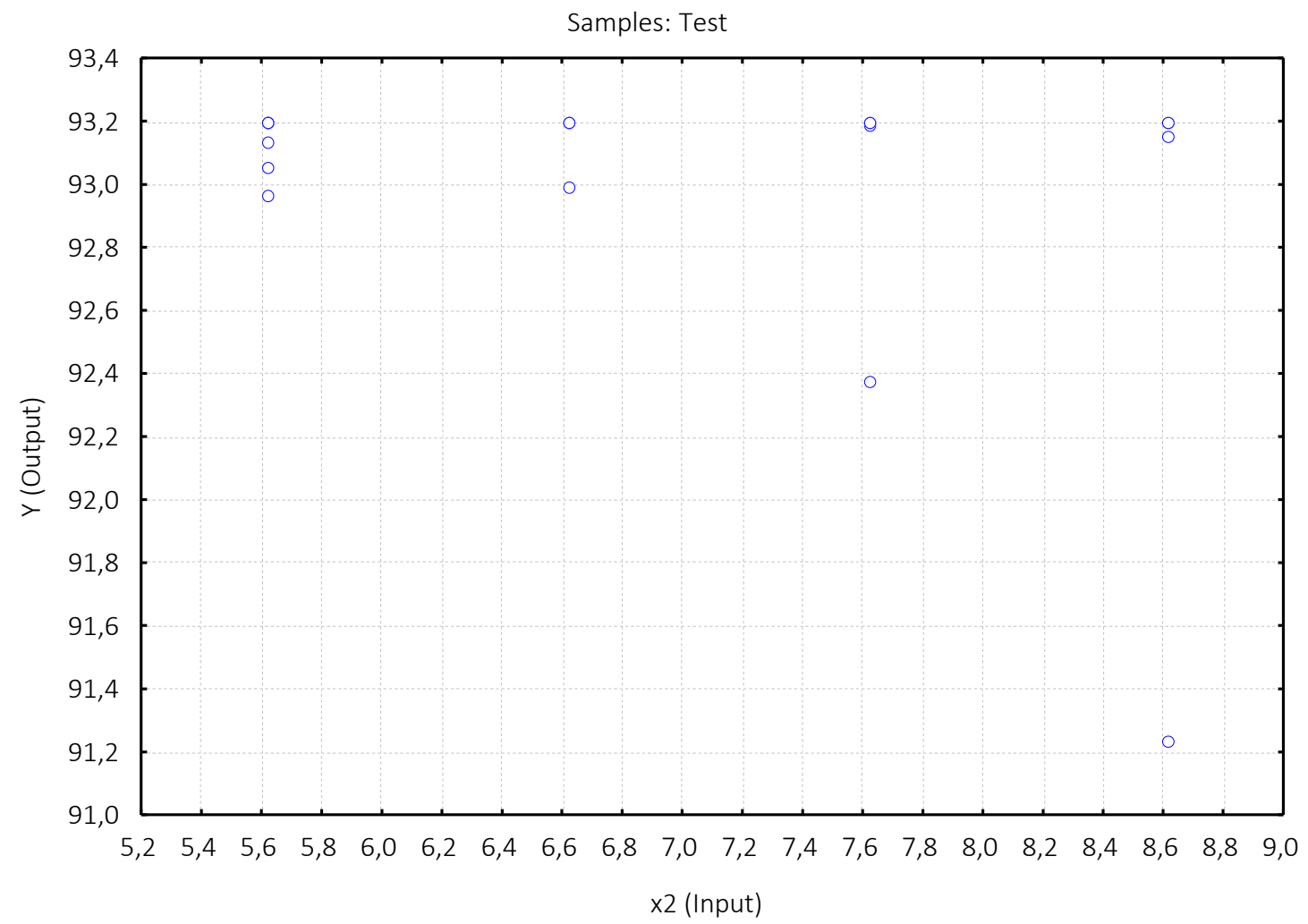

Figure 6. Mathematical dependence of the resulting index $(y)$ and the independent variable $x_{2}$ on the MLP 3-4-1 type neural network

In the case of constant of $\mathrm{X}_{1}$ and $\mathrm{X}_{3}$ and the existence of three of the maintained scenarios $\mathrm{X}_{2}$, the level of consumer total expenditure of households remains at $6.8 \%$ to $6,181.49 \mathrm{UAH}$. However, a decrease in the resulting indicator in the three development scenarios has the variability of the situational precedent of constant $\mathrm{X}_{1}$ and $\mathrm{X}_{3}$ and the existence of three of $\mathrm{x}_{2}$ maintained scenarios in Table 7 (Figure 6).

Growth in the level of information and communication technology $\left(\mathrm{X}_{2}\right)$ may contribute to the reduction of purchases through digital marketplaceing, which, among other things, forms consumer aggregate household spending. In fact the breakthrough of digital processes can redirect the population towards financial investment, for example, in the digital stock market.

In the case of constant of $\mathrm{X}_{1}$ and $\mathrm{X}_{3}$ and the existence of three of the maintained scenarios $x_{3}$, the level of consumer total expenditures of households remains at $6.8 \%$. The reduction in the re- sulting indicator in the three scenarios of development has even greater variation in the previous version of the assumption (Figure 7).

When the situational precedent of constant $\mathrm{X}_{1}$ and $\mathrm{X}_{2}$ and the existence of three of $\mathrm{X}_{3}$ mentioned scenarios in Table 7, the current level of profitability is the most stable (see Figure 7). However, increasing its index to the value of 0.3 (or 30\%) makes a difference of $0.2 \%$. For the country's economy, such a growth in business profitability will have a positive effect on the financial inflows of public funds, which, in its turn, may return to the country's citizens through comprehensive social programs and subsequently cause a consumer boom.

Results of modeling of a situational precedent with constant $x_{3}$ and the existence of different values of $x_{1}$ and $x_{2}$ are shown in Figure 8.

It is seen that information technologies have a significant impact on consumer processes via structured standards for digital data exchange of 


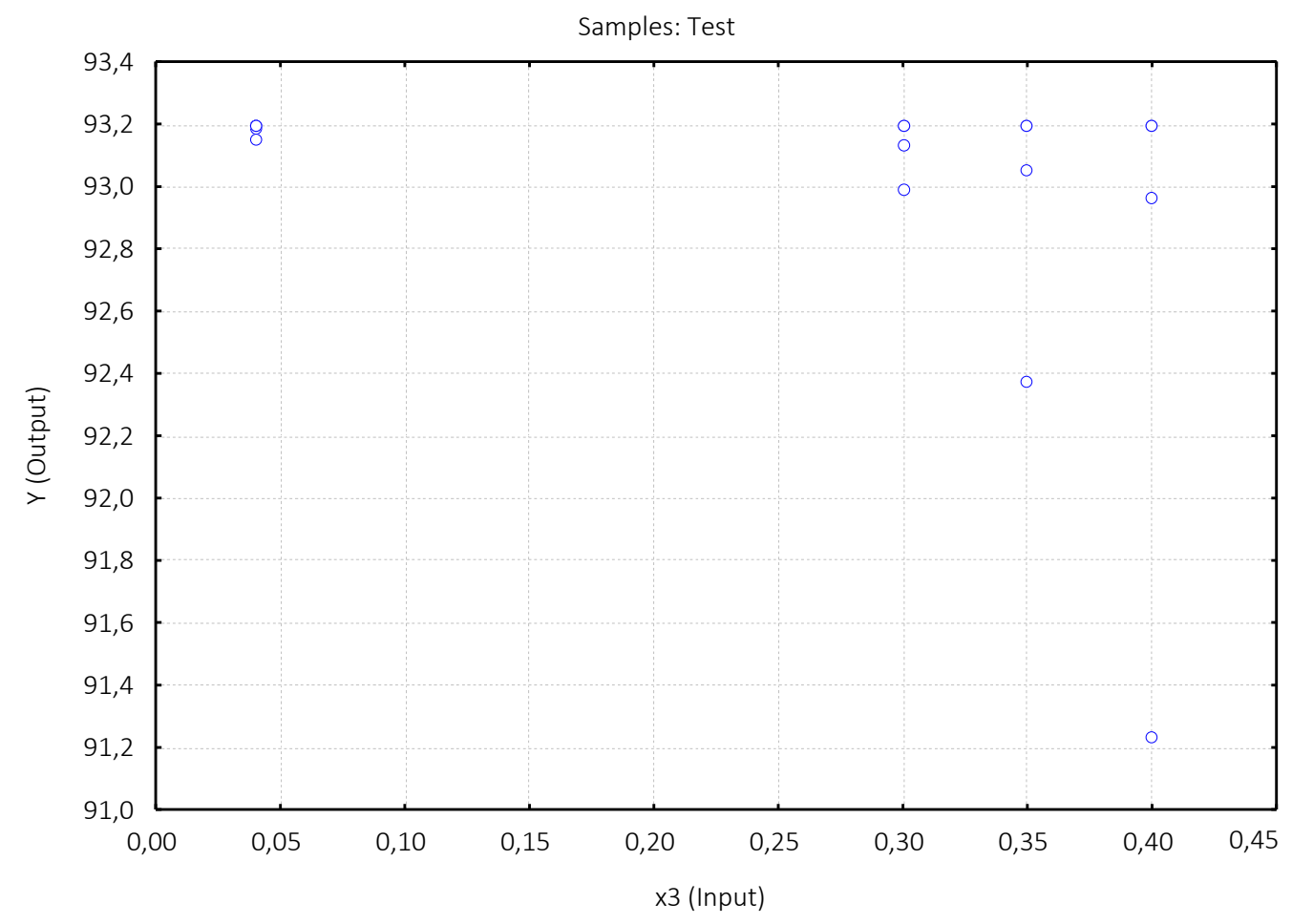

Figure 7. Mathematical dependence of the resulting index $(y)$ and the independent variable $x_{3}$ for the MLP 3-4-1 type neural network

x1 (Input), x2 (Input), Y (Output)

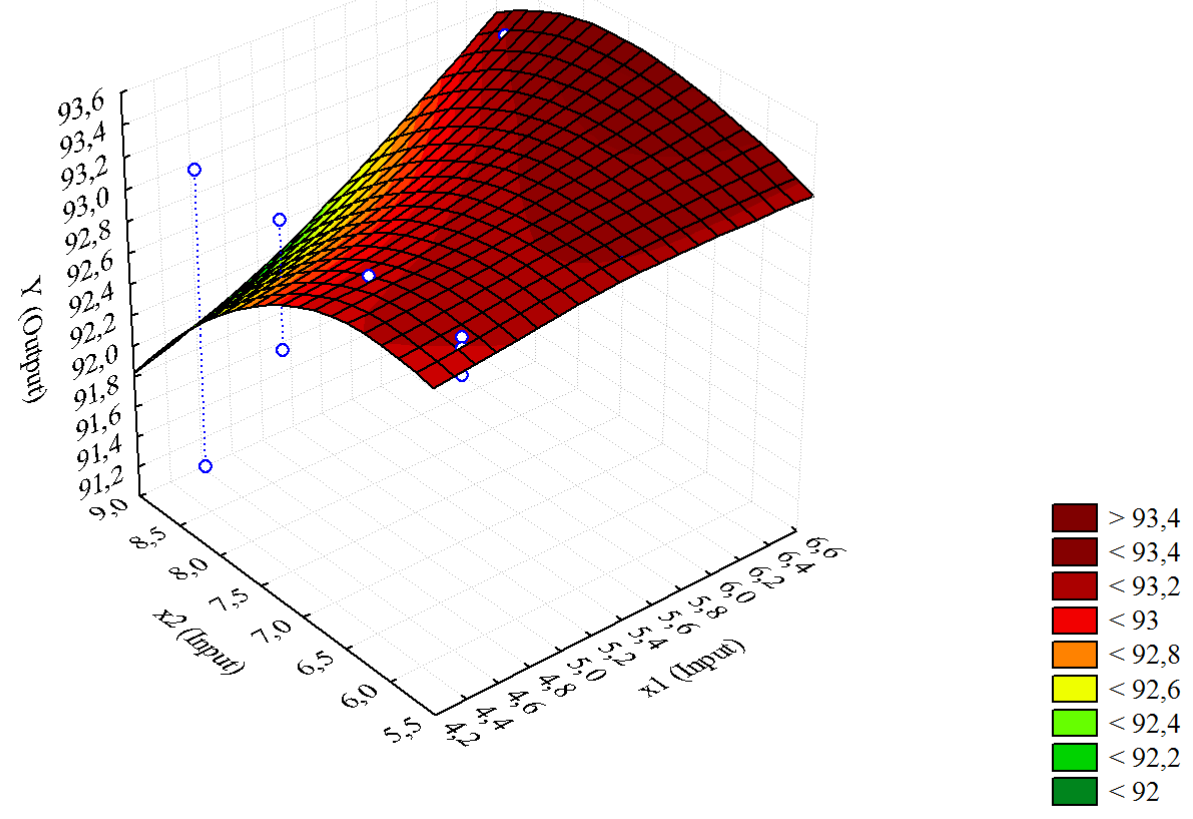

Figure 8. Cross-section of response surface of result indicator $(y)$ and independent variables of $x_{1}$ and $x_{2}$ for a neural network of MLP 3-4-1 type 


\section{x2 (Input), x3 (Input), Y (Output)}

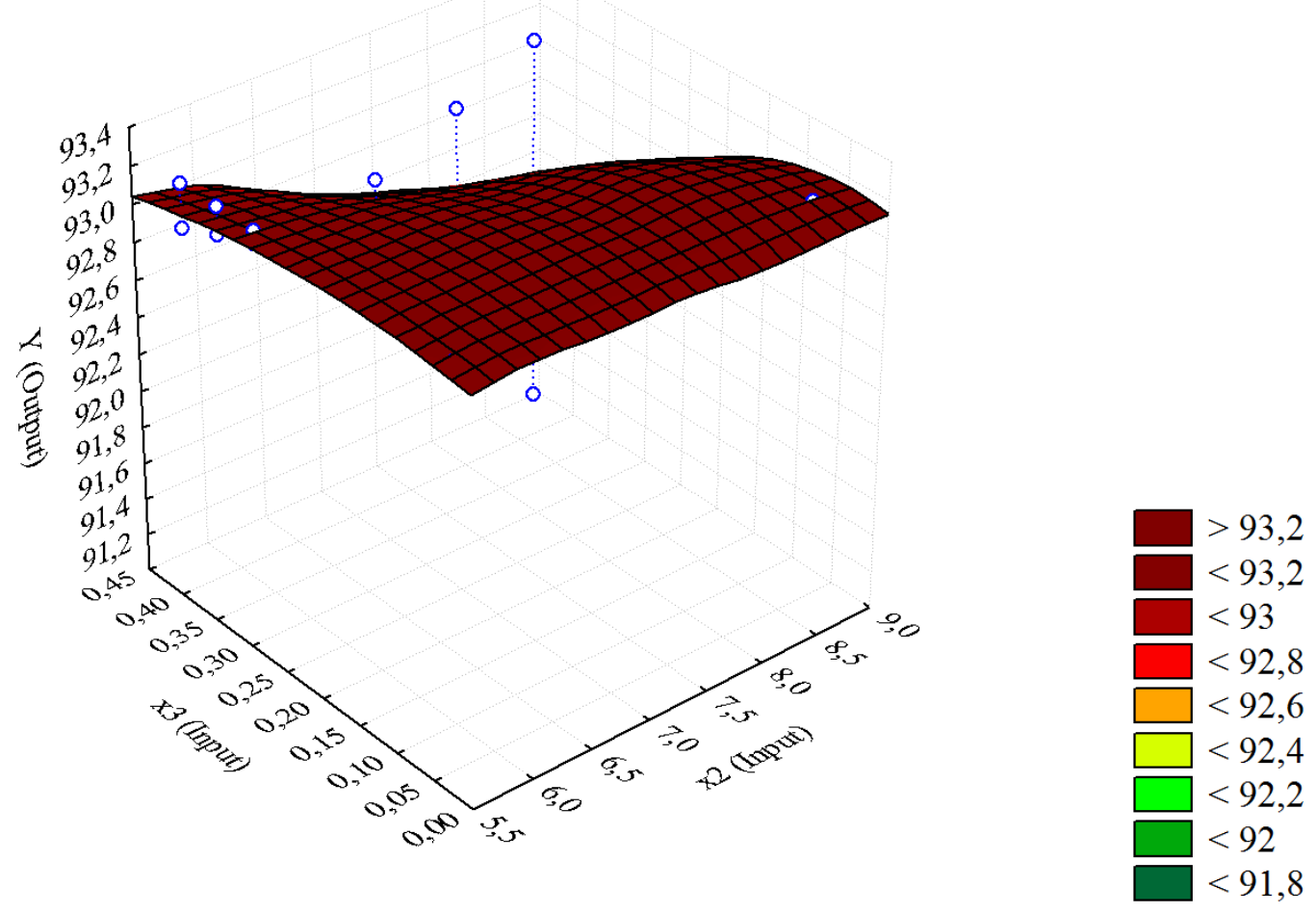

Figure 9. Cross-section of response surface of result indicator $(y)$ and independent variables $x_{2}$ and $x_{3}$ for a neural network of MLP 3-4-1 type

already known and prescribed algorithms, widespread use of computer capabilities, the provision of information in a form acceptable to the consumer, as well as the transfer of information regardless of the regulators of the state administration of a particular country.

A situational precedent, in which $x_{1}$ remains unchanged for different values of $x_{3}$ and $x_{2}$, is shown in Figure 9.

Figure 9 shows that there are no pronounced changes in the dynamics of the probable consumer consumption of household expenditures. This is due to the low level of high-tech production in Ukraine, which would meet international standards. Being one of the most important indicators of a country's potential for its development, business investment in ICT Development Index over time affects the level of business profitability and consumer confidence in manufactured goods.
A situational precedent, in which $x_{2}$ remains unchanged for different values of $x_{1}$ and $x_{3}$, is shown in Figure 10.

The wave oscillation of plane by the situational precedent (Figure 10) gives reason to argue that the level of network readiness has a significant impact on the business profitability. The study of the level of network readiness of Ukraine, the assessment of its impact on the economy of the country allow to establish the degree of dependence of the population's welfare on the information society. Business lags behind most of the leading economies through less active introduction and use of information technologies, which makes it difficult to realize the potential of fast networking and building smart factories. This forms a precedent for information-digital inequality between technology country-leaders and Ukraine, delayed investment in the economy, distrust in relations between economic subjects. 


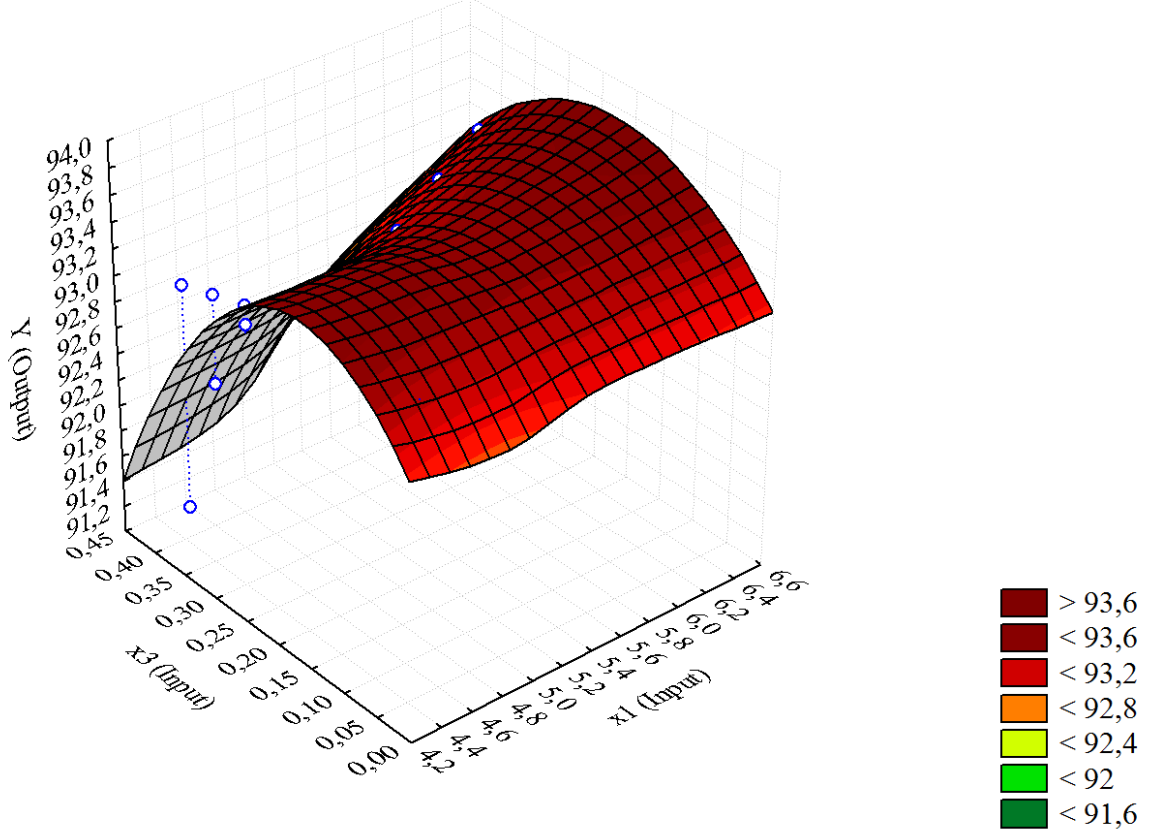

Figure 10. Cross-section of response surface of result indicator $(y)$ and independent variables of $x_{1}$ and $x_{3}$ for a neural network of MLP 3-4-1 type

\section{CONCLUSION}

Given the monitoring of status of outsourcing, marketplaces and retail in the world and in the regions, rather high requirements for business are determined both in terms of process and outcome approaches. The active position of the leading world countries' business is shown to maximize the success of international e-commerce. It is revealed that the established trend does not apply to all economies. Accordingly, a marketing analysis was conducted to determine the type of strategy that needs to be applied in order to activate business digitalization processes.

The current precedents of the economy digitization envisage a radical restructuring the interobjects, subjective-object and intercommunicational communications, a digital system of identification of the impact factors, the development of process protocols on variations of subject-object behavior and the adoption of managerial decisions in real time. Accordingly, the adoption of rational management decisions in real practical situations is complicated influenced by many factors and the variety of possible options for achieving business goals. Proceeding from this, the article generalizes the current architecture of the CPSS in the digital economy.

On the basis of the established low rate of business profitability with an increase in household consumption expenditures, a special case of low business readiness to improve marketing technologies in line with global trends has been identified. This study proposes a macroeconomic assessment of business readiness for the transition to a digital economy using a specific set of indices of domestic and international monitoring. This research deals not with probability, possibility, but with expectation. The highest degree of influence of indicator pairs such as the ICT Development Index and the gross profitability of the business on the country's economy, as well as the Networked Readiness Index and the gross profitability of the business in the country's economy on the aggregate consumer costs were revealed. 


\section{REFERENCES}

1. Coleman, A. (2015). Closer to home has benefits for UK firms. Raconteur Report, 0352, 16.

2. Deloitte. Global Powers of Retailing. (2018). Transformative change, reinvigorated commerce (48 p.). Retrieved from https://www2.deloitte.com/content/dam/Deloitte/ at/Documents/about-deloitte/ global-powers-of-retailing-2018. pdf

3. Eeles, Р. (2006). Что такое архитектура программного обеспечения? [Chto takoye arkhitektura programmnogo obespecheniya?]. Retrieved from https:// www.ibm.com/developerworks/ ru/library/eeles/index.html

4. Ek, I., \& Spiezia, V. (2017). Working Party on Measurement and Analysis of the Digital Economy. Directorate for Science, Technology and Innovation Committee on Digital Economy Policy (20 p.). OECD Headquarters, Paris.

5. Everett, K. (2015). Beware robots are coming. Future of outsourcing. Raconteur, 0352, 16.

6. Gavrylenko, T. V., \& Pavlenko, L. К. (2008). Бізнес-процеси підприємства: сутність, класифікація та оптимізація [Biznes-protsesy pidpryyemstva: sutnist, klasyfikatsiia ta optymizatsiia]. Management and Marketing in the 21st Century Business. Visnyk KNUTD, 18, 49-56.

7. Gurova, V. O., \& Sadekova, A. I. (2016). Оптимізація бізнеспроцесів на підприємстві в умовах кризи [Optymizatsiya biznes-protsesiv na pidpryyemstvi v umovakh kryzy]. Ukrainskyi zhurnal prykladnoi ekonomiky, 1(1), 75-82. Retrieved from http://dspace.tneu.edu.ua/handle/316497/2202

8. IEEE 1471 website. (2000). A Conceptual Model of Architecture Description. Retrieved from http:// www.iso-architecture.org/ieee$1471 / \mathrm{cm}$

9. Information Economy Report 2017: Digitalization, Trade and Development. (2017). United
Nations Conference on Trade and Development UNCTAD/IER/2017/ Corr.1. (130 p.).

10. IR Recearch. (2018). Key Findings from the 2018 E-Retailer Global Expansion Report. Retrieved from https://www.eshopworld.com/ wp-content/uploads/2018/08/ Aug2018_IR_GlobalExpansion_ KFR_eShopWorld-2.pdf

11. ITU. (n.d). Measuring the Information Society Reports (2014, 2015, 2016, 2017). Retrieved from https://www.itu.int/

12. Kovshova, I. O. (2016). Оптимізація бізнес-процесів як засіб підвищення ефективності діяльності промислових підприємств [Optymizatsiia biznes-protsesiv yak zasib pidvyshchennia efektyvnosti diialnosti promyslovykh pidpryiemstv]. Ekonomika. Menedzhment. Biznes, 1, 53-62. Retrieved from http://ekmair.ukma.edu.ua/ handle/123456789/11560

13. Kruglov, V. V., \& Borisov, V. V. (2002). Искусственные нейронные сети. Теория и практика [Iskusstvennyye neyronnyye seti. Teoriya i praktika] (2nd ed.) (382 p.). Hot Line-Telecom. Retrieved from https://www. twirpx.com/file/955659/

14. Legenchuk, S. F., Volsky, K. O., \& Vakun, O. V. (2016). Документування в бухгалтерському обліку: процесний підхід [Dokumentuvannia $v$ bukhhalterskomu obliku: protsesnyi pidkhid] (228 p.). Ivano-Frankivsk: G. Kushnir.

15. OMG. (2019). $M D A^{\oplus}-$ The Architecture of Choice for a Changing World. Retrieved from https:// www.omg.org/mda/

16. Verkhovna Rada of Ukraine. (2018). Cabinet of Ministers of Ukraine 17/01/2018, No 67р. Про схвалення Концепції розвитку цифрової економіки та суспільства України на 2018-2020 роки та затвердження плану заходів щодо їі реалізаціï [Pro skhvalennia Kontseptsiii rozvytku tsyfrovoi ekonomiky ta suspilstva Ukrainy na 2018-2020 roky ta zatverdzhennia planu zakhodiv shchodo yii realizatsii] Retrieved from https://zakon. rada.gov.ua/laws/show/67-2018\%D1\%80\#n250

17. Petrillo, A., Cioffi, R., \& Felice, F. D. (2018). Digital Transformation in Smart Manufacturing (Open access peer-reviewed Edited Volume). Retrieved from https:// www.intechopen.com/books/ digital-transformation-in-smartmanufacturing

18. Raconteur. (2018). Five predictions for the future of money. Retrieved from https://www.raconteur.net/ finance/predictions-future-money

19. Raconteur. (2017). The most attractive European countries for outsourcing. Retrieved from https://www.raconteur.net/ business-innovation/the-mostattractive-european-countries-foroutsourcing

20. Rizk, N. (2004). E-Readiness Assessment of Small and Medium Enterprises in Egypt: A Micro Study. Topics in Middle Eastern and African Economies, 6, 23. Retrieved from https://www.researchgate.net/ publication/228546820_E-readiness_assessment_of_small_and_ medium_enterprises_in_Egypt_A_ micro_study

21. Rudenko, O., Bezsonov, O., \& Romanyk, O. (2019). Neural network time series prediction based on multilayer perceptron. Development Management, 5(1), 23-34. https://doi.org/10.21511/ dm.5(1).2019.03

22. Sánchez, M. A. (2017). A framework to assess organizational readiness for the digital transformation. Dimensión Empresarial, 15(2), 27-40.

23. Sociam. (n.d.). Research Themes. Retrieved from https://sociam.org/ node/217/\#SC-anchor

24. State Statistics Service of Poland. (2019). Poland macroeconomic indicators. Retrieved from https:// stat.gov.pl/en/ 
25. State Statistics Service of Ukraine. (2019). Entrepreneurship development. Retrieved from http://www.ukrstat.gov.ua

26. Suominen, K. (2017). Accelerating Digital Trade in Latin America and the Caribbean (63 p.) (IDB Working Paper Series, No. IDB-WP-790), http://dx.doi. org/10.18235/0000636
27. World Economic Forum. (n.d.). The Networked Readiness Index (Reports 2010-2011, 2012, 2013, 2014, 2015, 2016). Retrieved from http://www3.weforum.org

28. World Trade Organization. (2018). The 2018 World Trade Report (236 p.). Retrieved from https://www.wto.org/english/ res_e/publications_e/world_ trade_report18_e_under_embargo.pdf

29. Zekanović-Korona, L., Tuđmana, F., \& Grzunov, J. (2014). Evaluation of Shared Digital Economy Adoption: Case of Airbnb (pp. 1791-1796). MIPRO 2014/DEGLGPS. 